David R. Benavides, MD, $\mathrm{PhD}$

Scott D. Newsome, DO

Neurol Neuroimmunol Neuroinflamm

2016;3:e281; doi: 10.1212/ NXI.0000000000000281
Supplemental data at Neurology.org/nn

\section{SEROTONIN-NOREPINEPHRINE REUPTAKE INHIBITORS MAY EXACERBATE STIFF-PERSON SYNDROME \\ OPEN}

Stiff-person syndrome (SPS) is a neuroimmunologic disorder characterized by painful spasms and muscle rigidity attributed to impaired inhibitory $\gamma$-aminobutyric acid (GABA) descending pathways. ${ }^{1}$ The immunopathogenesis remains unknown and the pathogenic significance of antibodies against glutamic acid decarboxylase (GAD) is controversial. Herein, we report 4 cases of anti-GAD65-positive patients with SPS (table e-1 at Neurology.org/nn) who had significant worsening of symptoms and disability with the serotonin-norepinephrine reuptake inhibitor (SNRI) duloxetine (table e-2). While causation cannot be proven, these observations suggest the importance of investigating the relationship between SNRI use and SPS clinical exacerbations (figure, A).

Case reports. Case 1. A 51-year-old woman with remote stroke developed gradual onset ataxia and frequent falls and required a cane to ambulate within 4 months of symptom onset (figure, B). Her symptoms failed to improve despite therapy with benzodiazepines, gabapentin, and tizanidine. She was prescribed duloxetine $30 \mathrm{mg}$ daily for pain. Over the next 4 weeks, she developed worsening spasms and gait dysfunction, and required a walker to ambulate. Five months after symptom onset, elevated anti-GAD65 antibodies were detected in serum $(11,350 \mathrm{U} / \mathrm{mL})$. EMG was consistent with the diagnosis of SPS. Duloxetine was discontinued and she was treated with IV immunoglobulin (IVIg), benzodiazepines, and tizanidine, with marked improvement in symptoms. She remains stable on IVIg at 14 months.

Case 2. A 38-year-old woman with anti-GAD65positive SPS, stable for 35 months with remote IVIg use, developed worsening hip pain and was prescribed duloxetine $30 \mathrm{mg}$ daily (figure, B). Within 2 weeks, she had significant worsening in musculoskeletal symptoms and complained of mental fogging. She was treated with benzodiazepines and duloxetine was discontinued. She gradually improved to her baseline over the course of 4 weeks and remains stable at 9 months.

Case 3. A 49-year-old woman with anxiety disorder and anti-GAD65-positive stiff-limb syndrome required intrathecal baclofen pump for symptom management (figure, B). After IVIg therapy and a period of relative clinical stability, she developed worsening anxiety and was prescribed duloxetine $30 \mathrm{mg}$ daily. Within 1 week of starting duloxetine, she developed painful spasms in her torso and legs, dysphagia, and respiratory distress. She was hospitalized and intubated for airway protection. Her examination was most notable for downbeating nystagmus and severe torso and leg rigidity. Duloxetine was discontinued, and she was treated with IVIg and clinically improved; however, she developed several medical complications and has had a fluctuating clinical course.

Case 4. A 30-year-old man with diabetes, hypothyroidism, depression, and anti-GAD65-positive SPS developed worsening mood and pain (figure, B). Within 8 months of symptoms onset, he was treated with steroids and prescribed duloxetine $30 \mathrm{mg}$ daily. He experienced severe painful spasms that were refractory to IVIg treatment over 18 months. Duloxetine was gradually titrated to $90 \mathrm{mg}$ daily and within 1 month of this increase, he developed continuous severe painful torso spasms requiring hospitalization. He underwent plasmapheresis for acute SPS exacerbation with modest improvement. After discharge from the hospital, he discontinued duloxetine and noted a remarkable improvement of musculoskeletal symptoms. His pain reliever and benzodiazepine use also decreased. He was treated with rituximab for maintenance immunotherapy and remains neurologically stable.

Discussion. These 4 cases support a role for noradrenergic circuits in the clinical exacerbation of SPS (figure, A). Previous studies found that rapidly injected clomipramine severely aggravated clinical symptoms in a patient with SPS. ${ }^{2}$ Clonidine, which is an $\alpha 2$ adrenergic receptor agonist, was shown to improve SPS symptoms. ${ }^{2,3}$ Taken together, these results may point to a critical function of noradrenergic signaling in the pathophysiology of SPS. ${ }^{3}$ These findings may also account for the observation that stress and anxiety often precipitate SPS attacks. 
A

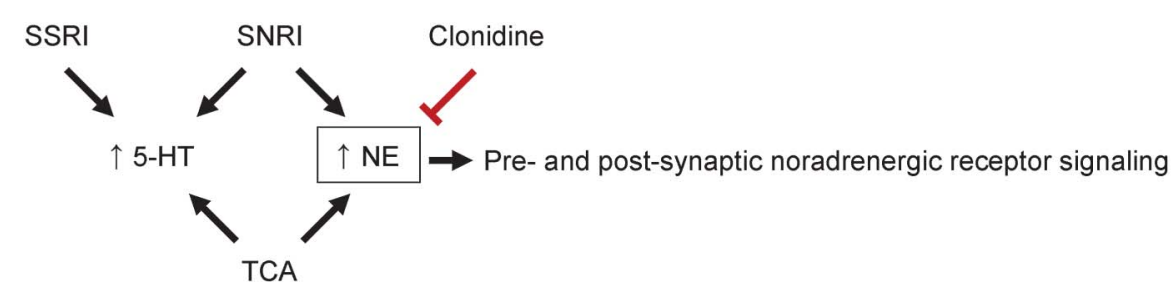

B
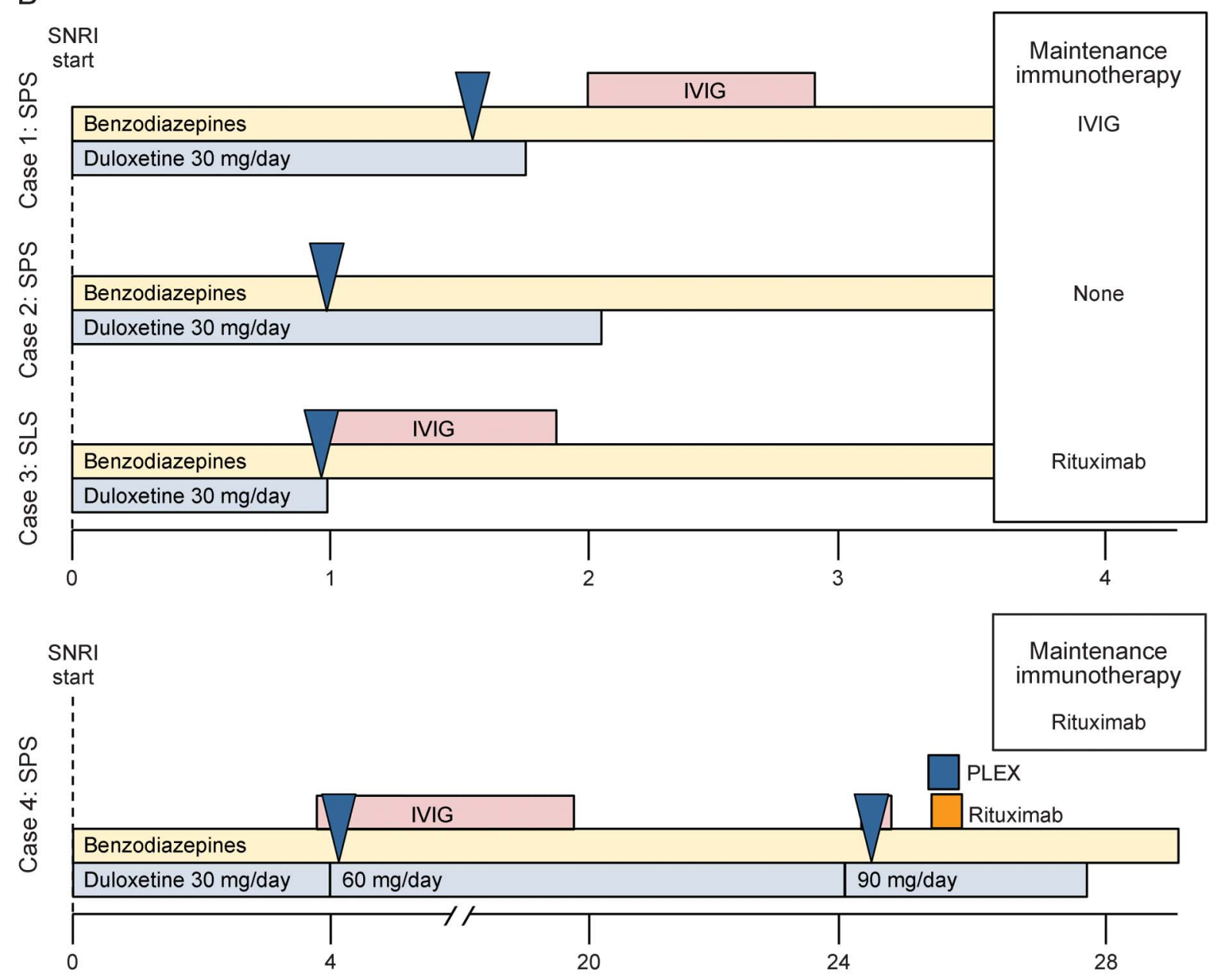

Time from SNRI start (months)

(A) Proposed model of serotonin and norepinephrine in SPS. (B) Clinical course of serotonin-norepinephrine reuptake inhibitor (SNRI) use in patients. Clinical exacerbations noted with blue arrow. 5-HT = 5-hydroxytryptamine; IVIg = IV immunoglobulin; NE = norepinephrine; PLEX = plasmapheresis; SLS = stifflimb syndrome; SSRI = selective serotonin reuptake inhibitor; TCA = tricyclic antidepressant.

Many patients with SPS have comorbid neuropsychiatric disorders, including anxiety and depression. ${ }^{1}$ The clinical observations presented here suggest caution should be taken when considering use of SNRIs in the management of comorbid neuropsychiatric disorders or musculoskeletal discomfort in patients with SPS. As we cannot exclude chance association, further study is required to identify the causal relationship between SNRI use and SPS clinical exacerbations.
These cases suggest the importance of investigating the relationship between SNRIs and SPS in a prospective case-control study. Early recognition and a careful review of medication use may help prevent disease exacerbations in SPS.

Notably, serum autoantibody testing was otherwise negative in all patients. Anti-GAD antibodies are associated with reduced GABA levels $s^{4,5}$ and appear to be associated with clinical symptoms of 
SPS when passively transferred into animal models. ${ }^{6}$ However, the pathogenicity of anti-GAD antibodies remains controversial. Autoantibodies to multiple antigens have been described in patients with SPS spectrum disorders. ${ }^{7}$ Further investigation is required into the role of antibodies to various other antigens in SPS spectrum disorders.

From Johns Hopkins University School of Medicine, Baltimore, MD. Author contributions: Study concept and design: Drs. Benavides and Newsome. Acquisition of data: Drs. Benavides and Newsome. Analysis and interpretation of data: Drs. Benavides and Newsome. Drafting of the manuscript: Drs. Benavides and Newsome. Critical revision of the manuscript for important intellectual content: Drs. Benavides and Newsome. Study supervision: Dr. Newsome.

Study funding: No targeted funding.

Disclosure: D.R. Benavides received research support from Mallinckrodt Pharmaceuticals and NIH/NINDS. S.D. Newsome served on the scientific advisory board for Biogen Idec, Genzyme, and Novartis; and received research support from Biogen Idec and Novartis (paid directly to his institution) and National Multiple Sclerosis Society. Go to Neurology.org/nn for full disclosure forms. The Article Processing Charge was paid by the authors.

This is an open access article distributed under the terms of the Creative Commons Attribution-NonCommercial-NoDerivatives $\mathrm{Li}$ cense 4.0 (CC BY-NC-ND), which permits downloading and sharing the work provided it is properly cited. The work cannot be changed in any way or used commercially.
Received July 16, 2016. Accepted in final form August 3, 2016.

Correspondence to Dr. Newsome: snewsom2@jhmi.edu

1. Murinson BB. Stiff-person syndrome. Neurologist 2004;10: 131-137.

2. Meinck HM, Ricker K, Conrad B. The stiff-man syndrome: new pathophysiological aspects from abnormal exteroceptive reflexes and the response to clomipramine, clonidine, and tizanidine. J Neurol Neurosurg Psychiatry 1984;47: 280-287.

3. Meinck HM, Conrad B. Neuropharmacological investigations in the stiff-man syndrome. J Neurol 1986;233: 340-347.

4. Dinkel K, Meinck HM, Jury KM, Karges W, Richter W. Inhibition of gamma-aminobutyric acid synthesis by glutamic acid decarboxylase autoantibodies in stiff-man syndrome. Ann Neurol 1998;44:194-201.

5. Dalakas MC, Li M, Fujii M, Jacobowitz DM. Stiff person syndrome: quantification, specificity, and intrathecal synthesis of GAD65 antibodies. Neurology 2001;57:780-784.

6. Hansen N, Grünewald B, Weishaupt A, et al. Human stiff person syndrome IgG-containing high-titer anti-GAD65 autoantibodies induce motor dysfunction in rats. Exp Neurol 2013;239:202-209.

7. Martinez-Hernandez E, Ariño H, McKeon A, et al. Clinical and immunologic investigations in patients with stiff-person spectrum disorder. JAMA Neurol 2016;73:714-720. 


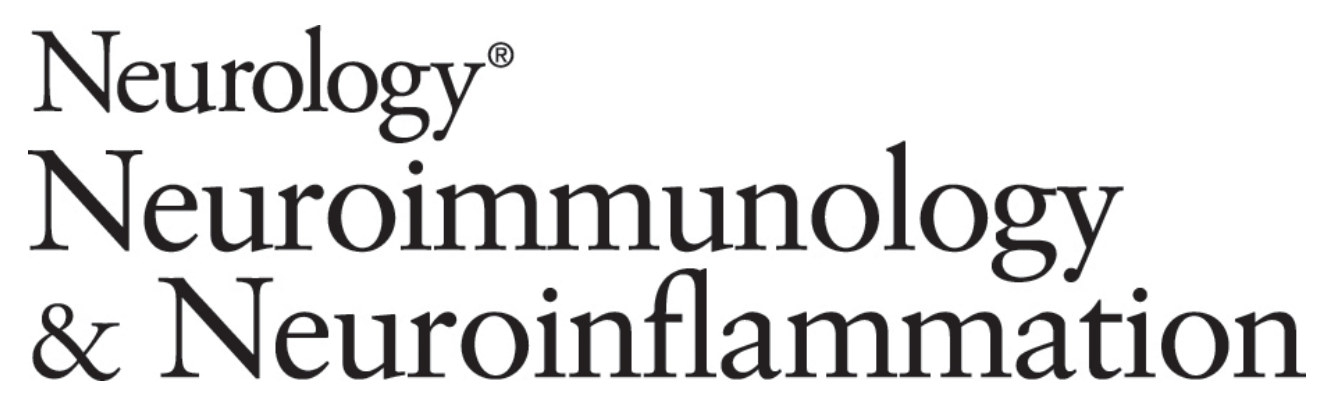

Serotonin-norepinephrine reuptake inhibitors may exacerbate stiff-person syndrome David R. Benavides and Scott D. Newsome

Neurol Neuroimmunol Neuroinflamm 2016;3;

DOI 10.1212/NXI.0000000000000281

This information is current as of September 28, 2016

Neurol Neuroimmunol Neuroinflamm is an official journal of the American Academy of Neurology.

Published since April 2014, it is an open-access, online-only, continuous publication journal. Copyright $\odot$ 2016 American Academy of Neurology. All rights reserved. Online ISSN: 2332-7812.

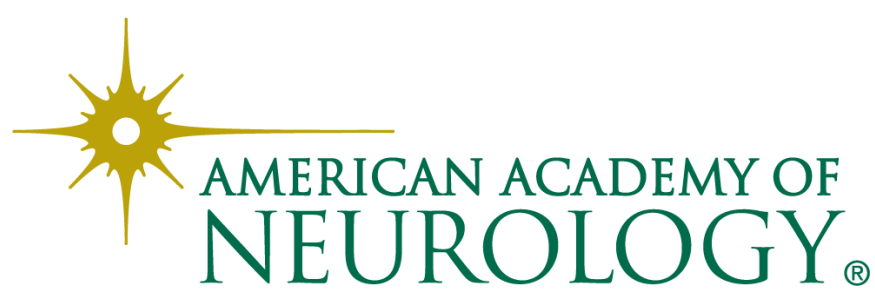




\section{Updated Information \& Services}

\section{Supplementary Material}

\section{References}

Subspecialty Collections

\section{Errata}

Permissions \& Licensing

\section{Reprints}

including high resolution figures, can be found at: http://nn.neurology.org/content/3/6/e281.full.html

Supplementary material can be found at: http://nn.neurology.org/content/suppl/2016/09/28/3.6.e281.DC1

This article cites 7 articles, 1 of which you can access for free at: http://nn.neurology.org/content/3/6/e281.full.html\#\#ref-list-1

This article, along with others on similar topics, appears in the following collection(s):

\section{All Medical/Systemic disease}

http://nn.neurology.org//cgi/collection/all_medical_systemic_disease All Pain

http://nn.neurology.org//cgi/collection/all_pain

Autoimmune diseases

http://nn.neurology.org//cgi/collection/autoimmune_diseases

Gait disorders/ataxia

http://nn.neurology.org//cgi/collection/gait_disorders_ataxia

Stiff person syndrome

http://nn.neurology.org//cgi/collection/stiff_person_syndrome

An erratum has been published regarding this article. Please see next page or:

/content/3/6/e295.full.pdf

Information about reproducing this article in parts (figures,tables) or in its entirety can be found online at:

http://nn.neurology.org/misc/about.xhtml\#permissions

Information about ordering reprints can be found online: http://nn.neurology.org/misc/addir.xhtml\#reprintsus

Neurol Neuroimmunol Neuroinflamm is an official journal of the American Academy of Neurology.

Published since April 2014, it is an open-access, online-only, continuous publication journal. Copyright $\odot$ 2016 American Academy of Neurology. All rights reserved. Online ISSN: 2332-7812.

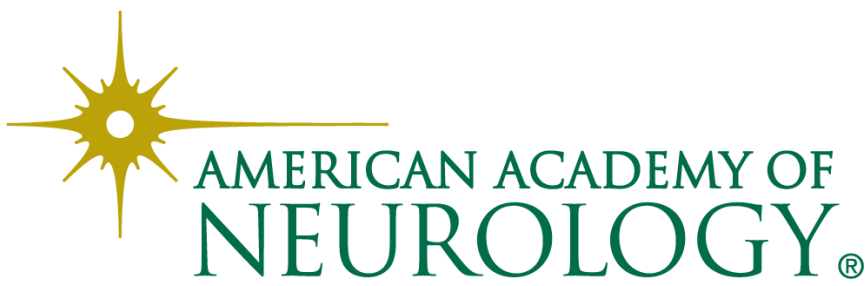




\section{CORRECTION}

Serotonin-norepinephrine reuptake inhibitors may exacerbate stiff-person syndrome

In the Clinical/Scientific Note "Serotonin-norepinephrine reuptake inhibitors may exacerbate stiff-person syndrome," by D.R. Benavides and S.D. Newsome, ${ }^{1}$ there is an omission in the figure. In panel C, the $\mathrm{x}$-axis label under Cases 1-3 should read "Time from SNRI (weeks)." The authors regret the error.

\section{REFERENCE}

1. Benavides DR, Newsome SD. Serotonin-norepinephrine reuptake inhibitors may exacerbate stiff-person syndrome. Neurol Neuroimmunol Neuroinflamm 2016;3:e281. doi: 10.1212/NXI.0000000000000281. 